\title{
The architecture of the corporate training system in the system of non-formal environmental education for sustainable development in Russia
}

\author{
Natalya Ryazanova ${ }^{1, *}$, Natalya Lobzhanidze $^{2}$, Elena Subbotina $^{2}$ \\ ${ }^{1}$ Moscow State Institute of International Relations (MGIMO University), 119454, 76 Vernadskogo \\ prospect, Moscow, Russia \\ ${ }^{2}$ National University of Oil and Gas «Gubkin University», 65-1 Leninsky Prospekt, Moscow, \\ 119991, Moscow, Russia
}

\begin{abstract}
The purpose of the study is to analyse the readiness of the education system to educate employees and train the personnel reserve in the system of non-formal environmental education and awareness. Mission: To develop a new integrated policy of environmental education for sustainable development at the federal level in the Russian Federation. Objectives: to evaluate the possibility and necessity of introducing transversal educational courses for Master students and teachers of additional education on the themes of the environmental cluster of Sustainable Development Goals (SDG); to substantiate comparability of separate modules, practical works and course as a whole for preparing students in general education for implementing education for sustainable development; to integrate SDG-related topics into existing directions of environmental education and additional education in general education; to promote efficient training of staff reserve in the system of informal education for sustainable development. The main research methods: the end-to-end system modelling of adult education, continuous learning, and professional development systems using ASSURE design algorithm for economic and qualitative assessment of learning outcomes. A novel methodology for the adaptation of corporate training for the system of additional environmental education at the state level was developed and proposed for the first time.
\end{abstract}

\section{Introduction}

The transfer of the Corporate Learning System (CLS) ideology to the public sector is justified by the high effectiveness that corporate learning has shown in its 80 years of existence. Perhaps not all of its elements should be transferred to the public system of general and additional education, but some elements are easy and useful to adapt. The first SCS appeared in the United States back in the 60 s in the form of "Training \& Development

\footnotetext{
${ }^{*}$ Corresponding author: natamgimo@gmail.com
} 
(T\&D) [1,2]. Initially, this system aimed at restructuring human resource management and thematic training, as well as increasing the motivation of employees of the company. The desired results were an increase in its competitiveness. The public sector of general and additional education does not necessitate competitiveness, but the actualisation of tools and methods to improve the relevance of educational programs and bring environmental education and awareness to a fundamentally new level, namely practice-oriented training and relevance of research topics for the federal constituent entities.

Education, which corresponds to the order of the professional community and the real problems of the environment was initiated by international organisations such as UNESCO, UNICEF, UNDP and others back in the 60 s of the twentieth century when the concept of Lifelong Learning appeared. Even then it became clear that the knowledge obtained in youth is not enough for a specialist for the whole life in conditions of rapid technological, social and economic transformations. Not only technology was changing, even ideology was changing. Society has moved from admiration for technology, devouring the resources of the environment to an understanding of the need for lean technologies and the formation of a new consciousness of consumption and production, which corresponds to the objectives of the SDG 12.

For pedagogical science, the LLL concept required the application of andragogic elements [3, p.7] to the existing requirements for skills and competencies, which allow adapting the learning systems to the needs of adults. This made it possible to create not only professional development courses for adult working people but also to create competitive courses in the training market, e.g., programmes for professional retraining and amount to more than 250 hours. Their content includes considerable practical material, as well as graduation work, which partly relates such training methods with the system of MBA education. A mixture of approaches and methods in modern pedagogy yields very effective results and advances the science to new frontiers. It becomes flexible, adaptive, and creative. According to UNESCO experts [4, pp. 28-35], this also requires a new role for the teacher, who should turn from a transmitter of knowledge into a companion, tutor, mentor, a person capable of lifelong learning. In 1993, UNESCO's International Commission on Education published a report "Education as a Hidden Treasure" on the problems and contradictions of the education actualisation, which articulated the global competencies that teachers and mentors who wish to contribute to science and society should possess: learning to learn, learning to work, learning to live together, learning to contribute to personal development [5]. The experts of the Council of Europe have shifted the emphasis from the activity of the teacher (the retransmitter of knowledge) to the activity of the students (on whom the development of the society of the future depends). It was in these studies that the competence of lifelong learning appeared in addition to political, social, communicative, and informational.

In Russia, the active promotion of SDG topics is just beginning. In 2019-2020, the youth movement "SDG School Leaders" was institutionalised as part of the Federal Children's Ecological and Biological Center (FDBC). From the beginning of the movement, it was already clear that the efforts of the schoolchildren themselves were not enough for the development and correct understanding of this topic in Russia. There came an understanding of the need to build a three-tiered training system for all levels: student young professional - teacher - teacher of additional education. It is this approach that can be considered comprehensive and easy to be adopted by corporate training technologies.

\section{Methods and materials}

The system of additional education for children and adults is a requirement of time. However, corporate education is not yet stipulated in the Russian Education Act, so the 
system of corporate training for environmental education can be built into the system of additional education.

In Russia, environmental education is not part of the system of formal education; however, it can effectively develop within this system in the form of elective disciplines or elective courses and circles. In the system of additional environmental education and enlightenment, the FDBC has adopted as its strategy the realization of additional education for children and adults, as well as additional professional education and implements general education programs in the space not limited by educational standards. This opens up great opportunities for creating courses of additional education and advanced training for adults who must soon learn to speak to students in the language of relatively new categories for Russia and the system of values declared in the framework of achieving the SDGs. For this purpose, a universal curriculum (Table 1) was created, which contains general and thematic parts. The general part includes the formation of leadership programs based on the project approach and the ideology of the SDGs. The special part includes training in the areas of tasks formulated in the SDG environmental cluster $(6,12,13,14$, and 15).

Table 1. Universal curriculum for corporate environmental education for children and adults

\begin{tabular}{|c|c|c|}
\hline Modules & & Learning content \\
\hline \multicolumn{3}{|c|}{$\begin{array}{c}\text { General part «LEADERSHIP PROGRAMS TO IMPLEMENT THE ENVIRONMENTAL CLUSTER } \\
\text { SDG» }\end{array}$} \\
\hline $\begin{array}{l}\text { Module 1: Sustainable } \\
\text { Development Goals }\end{array}$ & \multicolumn{2}{|c|}{$\begin{array}{l}\text { An overview of the SDGs in social, environmental, and economic areas. } \\
\text { Systematization of information. The basic principles of volunteering. }\end{array}$} \\
\hline $\begin{array}{l}\text { Module 2: } \\
\text { Fundamentals of Project } \\
\text { Activities }\end{array}$ & \multicolumn{2}{|c|}{$\begin{array}{l}\text { Development Algorithm and Project Life Cycle. Osterwalder's model. } \\
\text { SMART methodology. Project budgeting. }\end{array}$} \\
\hline $\begin{array}{l}\text { Module 3: Leadership } \\
\text { Skills }\end{array}$ & \multicolumn{2}{|c|}{$\begin{array}{l}\text { Approaches to leadership. Levels of leadership. Eisenhower matrix. } \\
\text { Creating a project presentation. Application of the tool "Minto's pyramid". } \\
\text { Self-presentation. Writing a resume. Basics of public speaking. Work in } \\
\text { social networks to promote the project. }\end{array}$} \\
\hline $\begin{array}{l}\text { Module 4: } \\
\text { Fundamentals of Team } \\
\text { Management }\end{array}$ & \multicolumn{2}{|c|}{$\begin{array}{l}\text { Tools and principles of team building. Methods of delegation and } \\
\text { distribution of responsibility. Principles and tools of Agile, Kanban, } \\
\text { Scrum, team motivation methods, team management methods. Elements of } \\
\text { conflictology for prevention and overcoming of conflict potential. Basics } \\
\text { of multilateral interaction within the project. }\end{array}$} \\
\hline $\begin{array}{l}\text { Module 5: Project } \\
\text { Management }\end{array}$ & \multicolumn{2}{|c|}{$\begin{array}{l}\text { Fundamentals, principles and tools of project management. Risk } \\
\text { assessments. Basics of systems thinking and practice of its application in } \\
\text { the project. Work with risks and work with partners in the project. }\end{array}$} \\
\hline $\begin{array}{l}\text { Module 6: Public and } \\
\text { Business } \\
\text { Communication }\end{array}$ & \multicolumn{2}{|c|}{$\begin{array}{l}\text { The basics of business and public communication. Image formation and } \\
\text { promotion in social networks, press release, content plan, basics of Web } \\
\text { and SMM-analytics. Strategic vision and community development. }\end{array}$} \\
\hline \multicolumn{3}{|c|}{$\begin{array}{l}\text { Thematic part «WORK ON SDG ENVIRONMENTAL CLUSTER PROJECTS» } \\
\text { (in the works) }\end{array}$} \\
\hline \multicolumn{2}{|c|}{$\begin{array}{l}\text { Module 1: Topic Update and Implementation of SDG } \\
6 \text { Objectives at Local and Regional Levels }\end{array}$} & \multirow{3}{*}{$\begin{array}{l}\text { Study of tasks in the direction of a particular } \\
\text { SDG. International and Russian } \\
\text { organizations carrying out work on a } \\
\text { particular SDG. Analysis of the state of } \\
\text { natural objects at the local and regional } \\
\text { levels. Opportunities for public participation } \\
\text { (children, adults, and NGOs) to improve the }\end{array}$} \\
\hline \multicolumn{2}{|c|}{$\begin{array}{l}\text { Module 2: Topic Update and Implementation of SDG } \\
12 \text { Objectives at Local and Regional Levels }\end{array}$} & \\
\hline \multicolumn{2}{|c|}{$\begin{array}{l}\text { Module 3: Topic Update and Implementation of SDG } \\
13 \text { Objectives at Local and Regional Levels }\end{array}$} & \\
\hline
\end{tabular}


Module 4: Topic Update and Implementation of SDG 14 Objectives at Local and Regional Levels

Module 5: Topic Update and Implementation of SDG 15 Objectives at Local and Regional Levels situation in the area of a specific SDG. Making a plan for research and project activities to implement their own project. Evaluation of the obtained results. Realization of opportunities to present the results of work at competitions of different levels for an independent assessment of the results.

Graduate work. Presentation and defense of the project

\section{Results}

The creation of corporate learning architecture in informal environmental education in Russia began with the school leadership program. One of the algorithms of curriculum design was then applied. This design allowed to connect the needs of additional environmental education for sustainable development in a three-level chain (Fig. 1).

Stage 1. Launch of the "SDG School Leaders" program. Development and implementation of additional general educational program "Children - SDG Leaders" in a modular form online. The program aims to involve students in the solution of international environmental problems through 'the SDG environmental cluster by teaching the basics of project activities and project design. The pedagogical expediency of the program results from the establishment of interdisciplinary connections and consolidation of theoretical materials in practice. The program is designed for 198 hours including 36 hours of theoretical classroom training and 42 hours of practical classroom work. The rest of the time budget is allotted for independent project work.

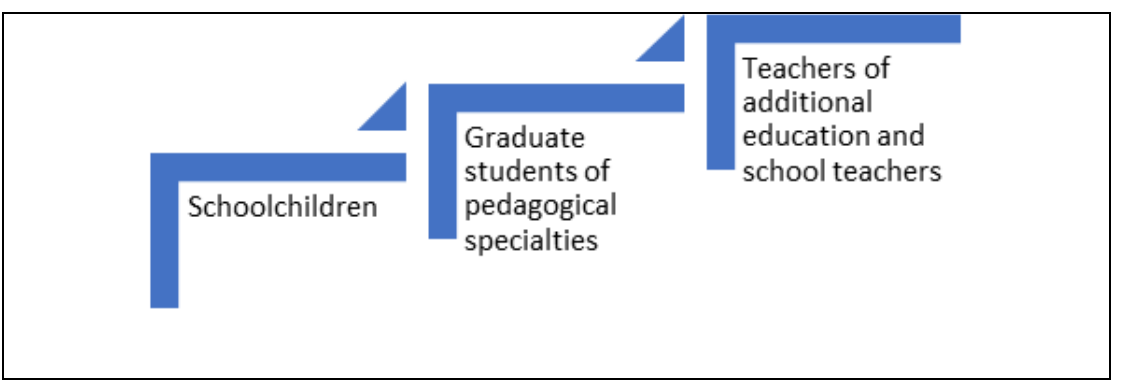

Fig. 1 Three-level model of corporate training in environmental education for sustainable development in Russia.

Stage 2. Development and implementation of a full (three-level) training course.

Table 2. Application of ASSURE algorithm to design a three-level training program

\begin{tabular}{|l|l|}
\hline \multicolumn{1}{|c|}{ Stage } & \multicolumn{1}{c|}{ Required actions and procedures } \\
\hline $\begin{array}{l}\text { A: analyze learner } \\
\text { characteristics }\end{array}$ & $\begin{array}{l}\text { Progressive analysis of the expected needs of learners at all three levels is } \\
\text { conducted. Entry skills before training begins are identified. The soft skills } \\
\text { that the training program will form are described. }\end{array}$ \\
\hline S: state objectives & $\begin{array}{l}\text { The target audience at each of the three levels of training is determined. } \\
\text { The optimal pace of learning and the conditions under which the skill of } \\
\text { project work is formed are established. Several degrees of skill formation } \\
\text { are proposed: from elementary to advanced. }\end{array}$ \\
\hline S: select, modify, or & The methods and set of materials used in compiling the course have been \\
\hline
\end{tabular}




\begin{tabular}{|l|l|}
\hline design materials & selected. Formats for offline and online training have been worked out. \\
\hline R: utilize materials & $\begin{array}{l}\text { Training materials and information for the first version of the course are } \\
\text { collected and systematized. A map of the course modules is made, the final } \\
\text { practical works on each module are described. }\end{array}$ \\
\hline response & $\begin{array}{l}\text { Extensive feedback was received from the regions about the need for a } \\
\text { project-based SDG training course. The request was formalized in the form } \\
\text { of verbal motivated justifications in the reports of pre-service teachers and } \\
\text { school teachers at conferences, as well as in the form of written requests to } \\
\text { the Directorate of the FDCC to hold such educational courses. Possible } \\
\text { options for independent work of different levels of students and topics of } \\
\text { final projects at the end of the course were discussed and developed. }\end{array}$ \\
\hline E: evaluate & $\begin{array}{l}\text { Evaluation of the expected learning outcomes in the Kirpatrick approach is } \\
\text { planned. Decisions to improve and evolve the course will be made as all } \\
\text { three levels of the training course are implemented. Evaluation of the } \\
\text { course authors' work is ongoing and planned for the future by the Scientific } \\
\text { Office, an expert structure within the FDBC that includes 128 educators } \\
\text { with advanced degrees from all administrative units of the Russian } \\
\text { Federation. }\end{array}$ \\
\hline
\end{tabular}

D. Kirpatrick's model provides for 4 levels of assessment of effectiveness by the results of training: level 1 - reaction, how the trainees react to the events of training after it; level 2 - learning, whether the trainees were able to apply in practice the new knowledge; level 3 - behavior, whether the trainees themselves could identify the environmental problem and form a plan of project work; level 4 - results, whether all stages of project work and goal setting to solve the environmental problem the trainees were able to implement correctly and productively.

In 2020 on the basis of the FDBC the Russian Academy of Education was awarded the status of the Federal innovation platform for the project "Eco Station", aimed at creating additional training places in the system of additional education for schoolchildren. Six areas of additional education are being implemented under the Ecostation project: AGRO, BIO, Forestry, Eco-monitoring, Design, and PROFI. The areas of the SDG agenda and the project works of the students were linked to the areas of work of the Ecostation project (Table 3):

Table 3. Correlation of the SDG agenda directions with the directions of work of the Ecostation project

\begin{tabular}{|c|c|c|}
\hline SDG Goal & SDG wording & $\begin{array}{c}\text { Areas of work of } \\
\text { the Eco Station } \\
\text { project }\end{array}$ \\
\hline $\begin{array}{l}\text { SDG } 6 \text { "Clean } \\
\text { Water and } \\
\text { sanitaiton" }\end{array}$ & $\begin{array}{l}\text { Ensuring availability and efficient use of water resources } \\
\text { and sanitation for all }\end{array}$ & $\begin{array}{l}\text { ECOMONITORING } \\
\text { DESIGN } \\
\text { PROFI }\end{array}$ \\
\hline $\begin{array}{l}\text { SDG 12: } \\
\text { Responsible } \\
\text { Consumption } \\
\text { and Production }\end{array}$ & $\begin{array}{l}\text { Ensuring the transition to sustainable consumption and } \\
\text { production patterns }\end{array}$ & $\begin{array}{l}\text { AGRO } \\
\text { BIO } \\
\text { FORESTRY } \\
\text { DESIGN } \\
\text { PROFI }\end{array}$ \\
\hline $\begin{array}{l}\text { SGG 13: } \\
\text { Climate Action } \\
\text { SDG 14: Life } \\
\text { Below Water } \\
\text { SDG 15: Life } \\
\text { on Land }\end{array}$ & $\begin{array}{l}\text { Taking urgent action to combat climate change and its } \\
\text { effects } \\
\text { Conservation and sustainable use of the oceans, seas and } \\
\text { marine resources for sustainable development } \\
\text { Protecting and restoring terrestrial ecosystems and } \\
\text { promoting their sustainable use, sustainable forest } \\
\text { management, combating desertification, halting and } \\
\text { reversing land degradation and halting biodiversity loss }\end{array}$ & $\begin{array}{l}\text { AGRO } \\
\text { BIO } \\
\text { ECOMONITORING } \\
\text { FOREST } \\
\text { DEVELOPMENT } \\
\text { DESIGN } \\
\text { PROFI }\end{array}$ \\
\hline
\end{tabular}


The technology of the project implementation is described in Table 4.

Table 4. Technology of implementation of three-level corporate training

\begin{tabular}{|c|c|c|c|}
\hline Level & Target & $\begin{array}{l}\text { Educational } \\
\text { technology }\end{array}$ & Educational outcome \\
\hline $\begin{array}{l}\text { Level 1: } \\
\text { Schoolchildren }\end{array}$ & $\begin{array}{l}\text { Updating the SD agenda } \\
\text { in cognitive, research, } \\
\text { and project work }\end{array}$ & $\begin{array}{l}\text { Leadership } \\
\text { training course } \\
\text { "Project work" } \\
\text { (active learning) }\end{array}$ & $\begin{array}{l}\text { Preparing research and } \\
\text { project works for presentation } \\
\text { at conferences, submitting to } \\
\text { and winning contests }\end{array}$ \\
\hline $\begin{array}{l}\text { Level 2: } \\
\text { Postgraduates }\end{array}$ & ool trai & \multirow{2}{*}{$\begin{array}{l}\text { Educational } \\
\text { course "Design } \\
\text { of educational } \\
\text { programs for the } \\
\text { SDG agenda" } \\
\text { (active learning) }\end{array}$} & \multirow{2}{*}{$\begin{array}{l}\text { Development of a LMC for } \\
\text { each of the SDGs (Table } 3 \text { ) of } \\
\text { the Environmental Cluster. } \\
\text { Organization of project work } \\
\text { by groups of students. } \\
\text { Development of new training } \\
\text { courses in digital didactics for } \\
\text { supplementary education } \\
\text { programs for schoolchildren. }\end{array}$} \\
\hline $\begin{array}{l}\text { Level 3: } \\
\text { Teachers of } \\
\text { additional } \\
\text { education, school } \\
\text { teachers }\end{array}$ & $\begin{array}{l}\text { Implementing the SDG } \\
\text { agenda in additional and } \\
\text { basic education courses } \\
\text { for schoolchildren }\end{array}$ & & \\
\hline
\end{tabular}

\section{Analysis}

"The Children - SDG Leaders" program is implemented remotely. The modules are completed with tasks on creating their environmental socially-oriented projects, public speaking skills and promoting environmental values and SDG topics in social networks and their school and neighbourhood. The result of the training is the defence of their own implemented project. Thus, the program can be an environmental leadership course. The system is built in such a way that all the topics and content of the modules are considered at a different level: for pupils - mastering of new knowledge, acquisition of new skills, disclosure of own potential; for master students - setting a scientific problem in the chosen direction of SDG, formation of a scientific work program, development of a pedagogical model, evaluation of the results of the implementation of the pedagogical model; for teachers of additional education and school teachers - mastering of the basics of educational management of students' project activity, mastering of the SDG environmental cluster tasks, highlighting topical local and regional problems.

The implementation of the ASSURE design algorithm for developing an educational program makes it possible to achieve high detail and high quality at each level of the program, as well as it is perfect for developing a large modular course with feedback and evaluation of the expected educational result.

To assess the effectiveness of the results in the corporate training system it is customary to use such methods as [1,2]: Tyler's Objectives Approach; - Scrivens' Focus On Outcomes model; - Stufflebeam's CIPP model; - CIRO scheme; - Guba's Naturalistic Approach; Bruce Aaron's VModel; - Kirkpatrick and Phillips' model; - Pearson's Efficacy of learning model, etc. But to implement environmental learning for sustainable development, where monetization of benefits may not be at the forefront, Donald Kirkpatrick's model (1950s) is well suited.

\section{Discussion}

The distance format made it possible to include in the training program all comers, regardless of age, time zone, and starting level of training. The three-level program allowed for professional language and approaches that are understandable to both children and adults. Besides, the program is structured so that each trainee learns both the basics of 
project management and can learn how to integrate SDG topics into the technology of project work. With the possibility of obtaining state funding for the development of the full cycle of the three-tiered corporate training program will be possible free training of all comers with the receipt of a document of advanced training.

Now there is a stage of adaptation of training performance assessment to create performance metrics (impact metrics) $[6,7]$. We see our task in the fact that the participants were accustomed and comfortable to work in a project approach, and they could even popularize it. As many high-quality projects must act as possible take part in the competitions of different levels (regional, federal, international) and were presented there as widely as possible.

In the future, it is planned to use internships for master's students within the framework of the SDG Kids Leaders project, practical seminars for teachers, internal training sessions, external seminars, electronic resources, presentation of scientific experience at international conferences.

\section{Conclusion}

A three-layer environmental education model for sustainable development at the state level with the use of structural elements of corporate training was developed and proposed. Training programs for each level are developed. System of an estimation of the expected educational result by results of the introduction of a new type of training passes approbation. In connection with its introduction at the level of adult education there is the formation of new skills in functional training in the current job duties and the inclusion of new information in the work; the formation of an understanding of "corporate standards" in terms of relevant environmental learning for sustainable development - business efficiency and focus on results; formation and development of managerial competencies within a single "corporate" environmental learning and design system. The expected educational result is a new design of thinking of young people and mentors $[8,9]$, which is aimed at the formation of understanding of the basic positions of sustainable consumption and production, as well as the achievement of the SDG targets to be achieved at the global level by 2030 .

\section{References}

1. S. I. Tannenbaum, G. Yukl, Annual review of psychology, 43(1), 399-441 (1992).

2. The New World Kirkpatrick Model [Web resource]. http://www.kirkpatrickpartners.com/OurPhilosophy/TheNewWorldKirkpatrickModel.

3. European report on qual. Indic. of lll. Directorate-General of Educ. \& Cult. (European Commission, 2002).

4. P. Lengrand, Prospects of lifelong education. (AJ Cropley. Ed, 1979).

5. J. Delors, Learning: The treasure within. (UNESCO, 1998)

6. E. M. Dorozhkin, E. Yu. Shcherbina, The Education and Science J., 6, 65-74 (2013)

7. Ocenka effect. Obucheniyar resource] https://sberbank-university.ru/upload/edutech/EduTech_2.pdf.

8. M.A. Ganyushina, S.N. Kurbakova, E.G. Galizina, V.V. Lopatinskaya, N.Y. Ryazanova Hum. \& Soc. S. Rev., 6(7), 727-731 (2019)

9. S. Vologzhina, N. Ryazanova, V. Eroshenko, E3S Web of Conference, 169, 05005 (2020) 